\title{
Challenges of poor surface water drainage and wastewater management in refugee camps
}

\author{
Ajibade O.O..$^{*}$, Tota-Maharaj K. ${ }^{1}$, Clarke B. ${ }^{2}$ \\ ${ }^{* 1}$ University of Greenwich, Faculty of Engineering \& Science, Department of Engineering Science, \\ Medway Campus, Kent, ME4 4TB, England, UK \\ ${ }^{2}$ University of Surrey, Faculty of Engineering \& Physical Sciences, Department of Civil \& \\ Environmental Engineering, Guildford, Surrey, GU2 7XH, England, UK
}

Email: o.o.ajibade@greenwich.ac.uk

\begin{abstract}
Since refugee camps are meant to be temporary and setting them up usually require urgency, little attention has been given to provision of surface water drainage and to a lesser extent wastewater management. As the population of refugees in these camps continues to grow, the effectiveness of drainage infrastructure continues to diminish. In addition, availability of sufficient safe drinking water and wastewater management have become difficult in the refugee camps across the world. The present situation in refugee camps across the world, such as flooding and outbreak of water-related diseases in South Sudan refugee camps, has made the need for sustainable approach to solving the problems to be very urgent. One sustainable way of solving the problems of flooding and outbreak of diseases in refugee camps is to provide effective drainage and wastewater infrastructure that ensures all the wastewater are properly collected, treated and reused for various purposes such as agriculture, drinking, laundry and other relevant uses. This paper therefore presents the current state of drainage and wastewater management in two refugee camps and propose low-cost technologies for stormwater management, wastewater collection, treatment and potential reuse, suitable for these refugee camps.
\end{abstract}

Keywords: Drainage, Health, Low-Cost Technologies, Refugees, Wastewater Management.

\section{INTRODUCTION}

Wastewater in refugee camps includes greywater from kitchens, laundry and bath places, stormwater from rainfall, snowfall and precipitation events, and blackwater from urine and excreta [1]. Wastewater contains plant nutrients such as nitrogen and phosphorus compounds, biodegradable organic compounds such as leaves and paper products, nonbiodegradable organic compounds such as insecticides and cleaning agents, inorganic compounds that contains heavy metals such as Zinc and Lead, and pathogens such as bacteria, protozoans and viruses [1-4]. Poor management of surface water and wastewater in refugee camps can lead to illnesses, infections and epidemics [5]. Although greywater and stormwater may not contain pathogens when they are newly generated, but when allowed to pond, they can become breeding ground for disease vectors such as mosquitoes which is responsible for transmitting Malaria, Dengue, West Nile virus, Chikungunya, Yellow fever, Filariasis, Saint Louis Encephalitis, Western Equine Encephalitis, Eastern Equine Encephalitis, LaCrosse Encephalitis and the Zika virus [6-7]. Improper wastewater and surface water management related diseases have been reported in various camps. These include malaria affecting Internally Displaced Persons (IDPs) across
Ugandan camps. Over ninety United Nations High Commissioner for Refugees (UNHCR) refugee camps in Africa and Asia are affected by malaria [8-9], Cholera and Malaria in refugee camps along the border between Syria and Turkey [10] and measles in refugee camps in Kenya, Ethiopia, Tanzania and other UNHCR refugee camps across Africa and Asia [9;11;12]. Other diseases that have been reported include Hepatitis E among refugees and IDPs in Upper Nile, South Sudan [10;13], bloody diarrhoea, watery diarrhoea and fever of unknown origin in Kosovar refugee camps in the former Yugoslav Republic of Macedonia and again over ninety refugee camps across Africa and Asia $[9 ; 14]$. Various approaches have been used by humanitarian agencies and organisations such as UNHCR, Oxfam, ActionAid and many other organisations in controlling illnesses, infections and diseases in refugee camps. Such approaches include provision of portable water supply facilities such as boreholes and water tanks, sanitation and hygiene facilities (toilets and latrines) [15]; scientific approaches such as administering vaccinations to refugees against known diseases [11] and social science approach by educating the refugees on behavioural change [16]. However, little has been done in using engineered approaches such as providing effective surface water drainage systems and 
wastewater management infrastructure to prevent and control diseases and ensure sustainable use of water by re-using and recycling wastewater.

\section{SURFACE WATER DRAINAGE PRACTICES IN REFUGEE CAMPS AND TEMPORARY SETTLEMENTS}

Very limited analysis has been conducted to assess the benefits of using sustainable drainage systems (SuDS) for surface water drainage in controlling and managing the flows of water in and around camps, preventing disease vectors and its demerits in terms of the damage conveyed waters can do to receiving natural hydro-systems (rivers) and the environment. Current surface water drainage facilities within refugee camps are simple open channel drainage systems designed to primarily convey stormwater out of the camps. This type of surface water drainage system is ineffective due to its inability to prevent localised ponding of surface water across the camps, manage flooding, manage greywater and blackwater in addition to stormwater attenuation. The prevention of cross-mixing of wastewater with stormwater and portable water sources is critical for public health. The results of ineffective drainage systems include [17]:

- Breeding of disease vectors in standing water

- Contamination of shallow water aquifers by stagnant water

- Schistosoma and other trematodes penetration into the skin of refugees and IDPs that have contact with standing water causing risk to health

- Potable water supply contamination by standing water and poorly managed wastewater.

To achieve workable solutions by implementing surface water drainage and wastewater management as a tool in controlling disease vectors and effectively manage flooding in refugee camps, improved designs, construction and maintenance techniques of surface water drainage systems and wastewater infrastructure is required [7]. Novel techniques are required to replace the current conventional open drainage channels which have been ineffective in draining wastewater and controlling disease vectors for several decades. Such improved designs of surface water drainage systems can incorporate wastewater recycling and re-use infrastructure whilst minimising localised ponding of surface water in the camps. Therefore, proper surface water drainage practices and wastewater management in refugee camps should include effective stormwater management, wastewater collection, treatment and reuse of wastewater. This can greatly improve the health and well-being of refugees and ensures sustainability of water use across the camps [17].

\subsection{Case study of Central African Republic (CAR)}

The Central African Republic (CAR) shares boundary with other African countries such as Cameroon, Chad, Republic of Congo, Democratic Republic of Congo, Sudan and South Sudan. The political unrest which started in December, 2013 in CAR forced over 2.3 million people to flee their homes to neighbouring countries as refugees while another hundreds of thousands have been internally displaced [18-19]. UNHCR reported that close to half a million people became refugees from their statistics of CAR refugees and IDPs in September 2016. Since the beginning of the recent unrest, there have been 452,000 refugees and 384,000 IDPs respectively from 2013 to 2015 [19-20]. The statistics from UNHCR shows that over 240,000 CAR refugees now live in refugee camps located in Cameroon, approximately 100,000 CAR refugees in CHAD refugee camps, over 70,000 CAR refugees in the Democratic Republic of Congo, and more than 20,000 CAR refugees in Republic of Congo [20]. The above statistics of CAR refugees in neighbouring African countries does not include the new arrivals of approximately 120,000 CAR refugees in Cameroon, 17,500 in CHAD, 9000 in the Republic of Congo and about 15,000 CAR refugees in the Democratic Republic of Congo in 2016 [20]. Figures 1(a) and 1 (b) below show the location of CAR and its neighbouring countries on the continent of Africa.

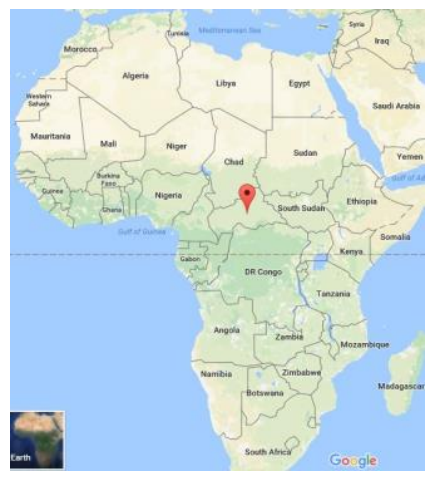

Figure 1(a). Location of Central African Republic on the Continent of Africa (Source: Google Maps, 2016a).

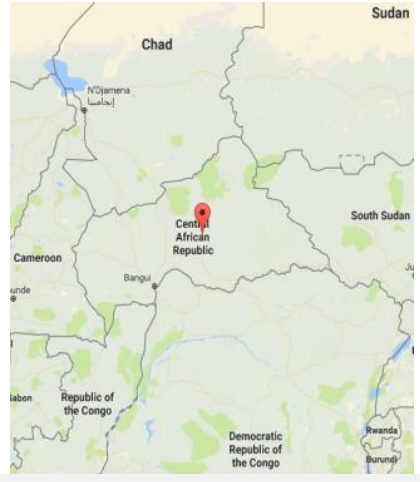

Figure 1(b). Location of Central African Republic and its neighbouring countries on the continent of Africa (Source: Google Maps, 2016b).
Since the population of CAR refugees migrating to camps in neighbouring communities continues to grow, proper management of wastewater in the camps requires urgent workable solution to prevent outbreak of diseases in the camps. Furthermore, the availability of sufficient water supply and proper wastewater management has become immense challenge in these congested IDP camps across CAR [19]. Figures 2(a) and 2(b) below illustrate the current state of insufficient safe drinking water and poor surface water drainage infrastructure in CAR IDP camps.

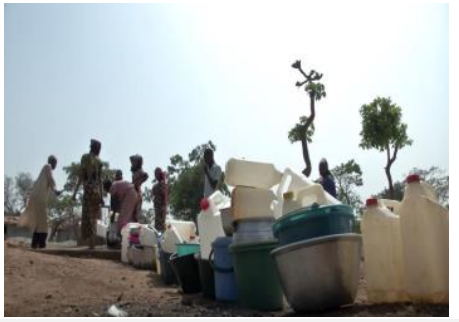

Figure 2(a). Insufficient safe drinking water supplies (source: UNHCR, 2016a).

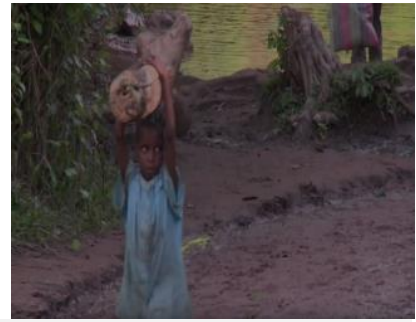

Figure 2(b). Poor states of surface water drainage (source: UNHCR, 2016a).
The problems of insufficient water supply and poor surface water drainage in CAR IDP camps and refugee camps in neighbouring communities require urgent sustainable solutions. Such sustainable solutions can ensure that all the wastewater is properly collected, treated and re-used. Reusing properly treated wastewater in refugee camps and IDP camps 
for irrigation, laundry and other purposes will reduce dependence on fresh water resources. This will ensure that there is more fresh water available for the refugees and IDPs for drinking, cooking and hygiene purposes, thereby improving their living conditions.

\subsection{Case study of South Sudan}

South Sudan is an African country that shares boundary with some other African countries such as Sudan, Central African Republic, Ethiopia, Kenya and Uganda. South Sudan became Africa's fifty third sovereign state on July 9, 2011, and has been experiencing violent conflicts that has made hundreds of thousands of South-Sudanese to become internally displaced from their homes [23-24]. Over 2.6 million of South Sudanese have become refugees [25]. The need for temporary accommodation for internally displaced South Sudanese and refugees from neighbouring countries that are in crisis such as the CAR has led to urgent set up of refugee camps in South Sudan. The refugee camps in South Sudan include Jamam, Maban, Bentiu and Gendrassa refugee camps. Figure 3(a) below illustrates the location of South Sudan and the neighbouring countries on the continent of Africa and Figure 3(b) illustrates migration of refugees from neighbouring countries into South Sudan.

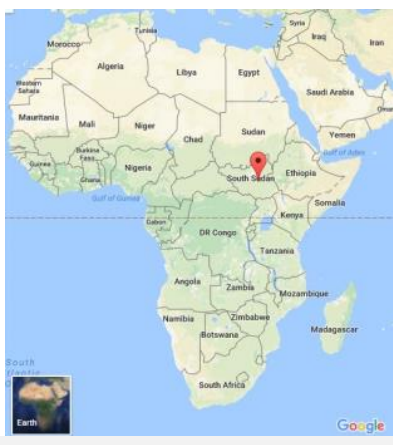

Figure 3(a). Location of

South Sudan on the continent of Africa (Source: Google Maps, 2016c).

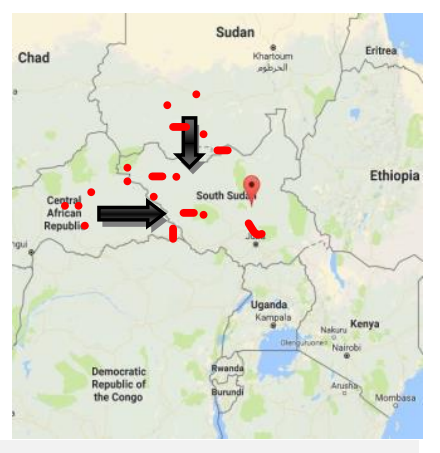

Figure 3(b). Arrows illustrating migration of refugees from neighbouring countries into South Sudan

(Source: Google Maps, 2016d)
Due to urgency of setting up these refugee camps, adequate attention was not given to surface water drainage and wastewater management in the camps. The results of absence of decent surface water drainage and wastewater management in South Sudan refugee camps include frequent flooding and spread of diseases such as cholera, diarrhoea and hepatitis E [28-29]. Some of the identified causes of frequent flooding in South Sudan refugee and IDP camps are their location in lowlying areas and high rainfall intensity [7]. Figures 4(a) and 4 (b) below illustrate incidents of surface water flooding across the Jamam and Bentiu camps respectively after heavy rainfall events.

The poor state of surface water drainage and wastewater infrastructure in South Sudan refugee camps requires urgent workable solution to mitigate outbreak of water-related diseases among the refugees and frequent flooding in the camps. The use of combination of levee and engineered systems (drainage pipes, canal and pumping) has been designed by the Dutch consultancy firm, Grontmij after the flooding event of 2014 in Bentiu camp [7], but Reed (2015; as cited by Tota-Maharaj, 2016) found such systems to be unsustainable due to high costs of implementation and operation, as heavy pumping is required.

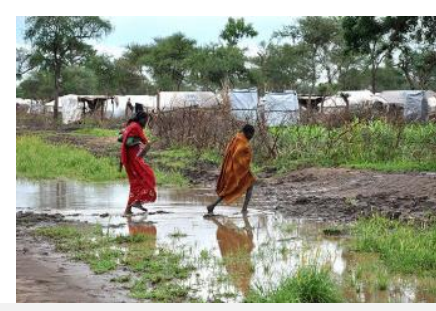

Figure 4(a). Flooding event in Jamam refugee camp in South Sudan (Source: McDonald, 2012).

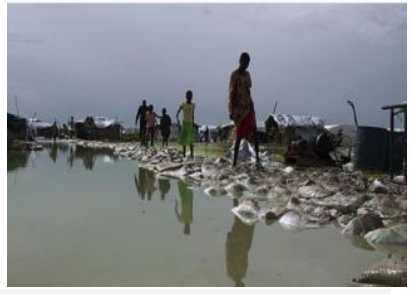

Figure 4(b). Flooding event in Bentiu refugee camp in South Sudan

(Source: Grontmij, 2015 as cited by Tota-Maharaj, 2016).

\section{PROPOSED TECHNOLOGIES FOR SURFACE WATER DRAINAGE AND WASTEWATER MANAGEMENT IN REFUGEE CAMPS}

The proposed technologies focus on stormwater, greywater and blackwater management in the camps. For all the chosen and proposed technologies, the inputs are either (a) stormwater (b) greywater or (c) blackwater whilst the outputs are effluents that can be safely used for irrigation, laundry, cooking and other purposes within the camps. The aims of proposing these technologies for use in refugee and IDP camps are to keep the camps free of stagnant water, mitigate flooding, reserve water for drought conditions, protect the environment, prevent contamination of drinking water sources and groundwater, and encourage sustainable use of water by reducing dependence on fresh water for irrigation, laundry and other uses in the camps. These proposed technologies and water infrastructures adopt an ecological sanitation approach for wastewater management in the camps. The ecological sanitation approach ensures that stormwater and other wastewater do not mix, therefore, simple methods can be used to store, treat and recycle water within the camps [31]. Factors considered in choosing the technologies for wastewater management in refugee and IDP camps include low cost of construction, ease of implementation, ease of maintenance, sustainability and effectiveness.

\subsection{Proposed stormwater management technologies for refugee camps}

\subsubsection{Filter drains}

Filter drains are trenches filled with permeable materials such as crushed stone or gravel, geotextile material and perforated pipes for water conveyance [32]. They are SuDS that can be used to effectively collect surface water, trap sediments and convey the filtered surface water to a different part of the camp. They are ideal technology for refugee camps and other temporary settlements because of their various advantages. Such advantages include low construction cost, low land take, ground water control and effective run-off drainage [33]. The major components of filter drains are permeable material such as gravel and crushed stones and perforated pipe near the end of the filter drain. Gravel and crushed stones which are the main material for construction of filter drains are sufficiently available 
across South Sudan and CAR [34]. A cross-section of proposed filter drain system is presented below in Figure 5. To prevent clogging of the filter drains and reduce need for frequent maintenance, greywater that contains oil and grease should be collected using different technologies. Properly constructed filter drains can achieve pollutant removal efficiency of $85 \%$ Total Suspended Solid (TSS), 83\% Total Lead, 81\% Total Zinc, 70\% Oil but limited Nitrogen and Phosphorus removal [33].

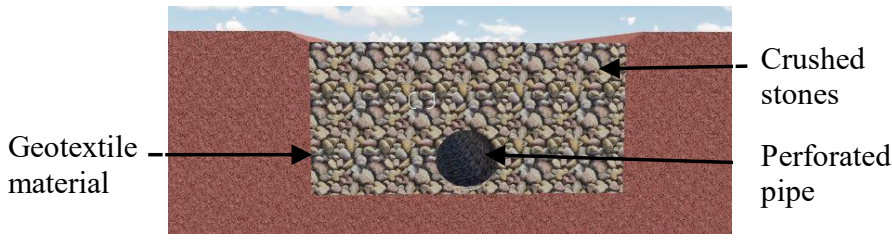

Figure 5. Cross-section of filter drain for stormwater management (Adapted from: Cambridge SUDS Design \& Adoption Guide, 2016).

The use of filter drains in the camps for surface water drainage and wastewater management will improve the environmental conditions of the camps in the following ways:

- $\quad$ The filtering capability of the filter drains will ensure that mass of pollutants in stormwater is significantly reduced to prevent contamination of the water sources, such as rivers in the camp, as well as groundwater.

- The high infiltration rate of the permeable materials of the filter drains will ensure that the camps are free of flooding and localised ponds of water that can serve as breeding ground for disease vectors.

\subsubsection{Tree pits}

Tree pits are part of the proposed SuDS for stormwater management in refugee and IDP camps. The tree pits capabilities include collecting, detaining and filtering stormwater efficiently to further reduce mass of pollutants in stormwater through nutrient and water absorption by the trees, and sediment trapping by soil in the pit while allowing water to pass through to the next component in the SuDS [36]. The effluent from the filter drains and surrounding area serve as influent for the tree pits. The main components of the tree pits are pit of sufficient volume, plant soil that is a mixture of sand, topsoil and compost only, ponding area, underdrain pipes, overflow pipes, and waterproof lining [37]. Citrus tree, mango tree and other trees with both economic and biodiversity values are recommended for the camps in South Sudan due to a range of ecological zones, providing habitat for the country's globally important biodiversity [38]. Figure 6 below shows cross-section of a tree pit. [37]:

The functions of the elements of the tree pit are as follow

i. Inlet points: The inlet points take effluent from the filter drains and the surrounding areas. It should be above the ponding area of the pit.

ii. Ponding area: This is the surrounding area of tree made a little lower than the ground around the pit. This is where stormwater ponds before it percolates through the soil in the pit.

iii. Engineered soil: The soil in the area marked out for the pit is removed to required depth and then the pit is filled with mixture of sand and topsoil to allow for adequate draining and filtering of stormwater. The engineered soil should be allowed to compact naturally by watering only. iv. Overflow pipe: This is pipe installed vertically to divert higher than usual volume of water in the pit. The top of the pipe should be above the surface of the tree pit but below surrounding ground level, and the lower part should be connected to the underdrain pipe. The top of the overflow pipe show also be fit with screen to prevent clogging.

v. Tree: The tree thrives on nutrients in stormwater and water in the pit. This way, the tree contributes to mass reduction of pollutant that are in form of useful nutrients for the tree survival. This is also an effective way of stormwater reuse in the camps, especially when the trees are fruit trees.

vi. Underdrain: It is a perforated pipe installed at the base of the pit at a gentle slope of about $0.5 \%$ to collect water that filters through the pit. The collected water can be directed to underground storage tank where it can be reused for various purposes in the camp or directed to farm on camp as irrigation water.

vii. Geotextile lining: It is only required as part of tree pit in camps with high water table to prevent saturation of the tree pit by groundwater.

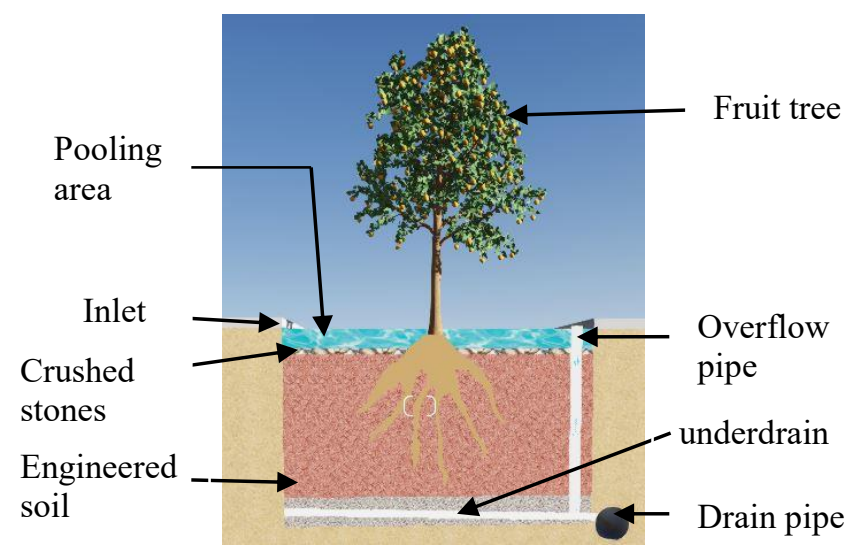

Figure 6. Cross-section of a tree pit for stormwater management (Adapted from Udale-Clarke, 2016).

\subsubsection{Under-drained swales}

Swales are part of the SuDS that can be used for conveyance and treatment of stormwater runoff in the camps. It is an effective component of the SuDS for flood management [39]. The major components of swales are grass lining, topsoil, crushed stone for filtering, engineered topsoil for filtering and to support plant growth and perforated pipe to convey filtered water. Swales can be used with Filter drains for higher pollutant removal efficiency [35]. Figure 7 below shows cross-section of a swale.

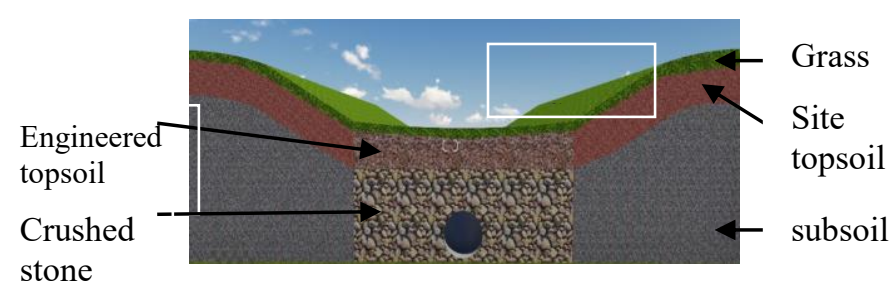

Figure 7. Cross-section of an under-drained swale for stormwater management (Adapted from: Cambridge SUDS Design \& Adoption Guide, 2016)

The grass lining on the surface of the swale is an important element of the swale due to its capability of reducing velocity of stormwater runoff and reducing mass of pollutant in stormwater by trapping sediments as stormwater is conveyed. 
Also, part of the conveyed stormwater runoff infiltrates to contribute to ground water recharge. Materials required for construction of swales, such as gravel and crushed stones, are available across South Sudan and CAR [34]. The main maintenance requirement of swales is cutting overgrown grass along the surface of the swale [35]. The maintenance can easily be done by the refugees using simple tools such as cutlass and garden rakes.

\subsection{Proposed greywater management technologies in refugee camps}

\subsubsection{Oil and grease traps}

Oil and Grease traps are simple wastewater treatment technologies that can effectively remove grease, fat and oil from greywater generated from kitchen, food processing areas, laundry and bathing areas in the camps [40-41]. The treatment techniques of oil and grease traps are based on difference in densities of water and the pollutants in greywater (fats, oils and grease). The densities of pollutants are much lower than density of water, therefore, the pollutants float above the water. The clear effluent can then be collected to be reused for various purposes in the camps or directed to the main drains [41]. The main components are inlet pipe to take in greywater, airtight access cover, baffled chambers to retain the pollutants and outlet pipe to convey treated water to the main drain or point of reuse. Figure 8 below shows the cross-section of a simple oil and grease trap system. Materials required for construction of oil and grease traps include PVC pipes and concrete [42].

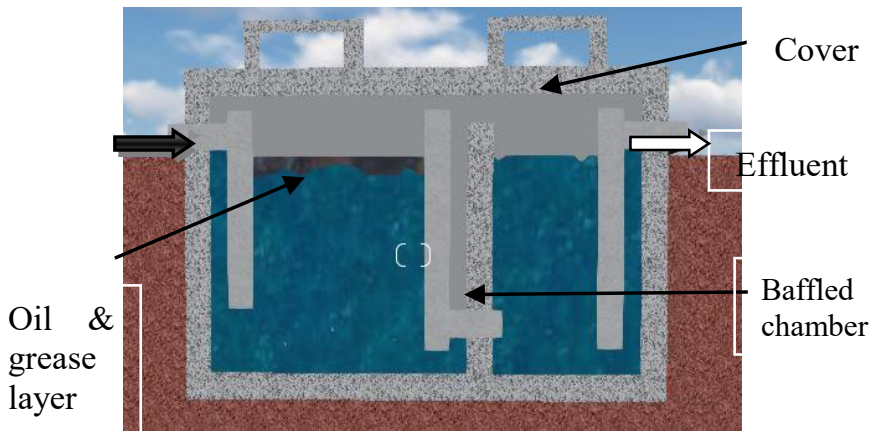

Figure 8. Cross-section of Grease Trap for greywater management (Adapted from: City of Carrollton Grease Interceptor Sizing Requirements, 2012).

\subsubsection{Container based technologies}

Container based technologies are simple, low-cost technologies which involves collecting greywater in containers such as tank and plastic water storage containers and directly reusing the collected greywater for irrigation [43]. Although greywater may look dirty due to food particles, grease, oil and even household cleaning items that it contains, it is safe to reuse greywater as irrigation water without any treatment. The chemical components of greywater such as nitrogen and phosphorus are beneficial to plants but become pollutants when they are directly released to rivers and other water sources in the camps. Figure 9(a) below illustrates greywater management using container based technology. The greywater should be prevented from having direct contact with edible parts of the irrigated plants [43]. The container based technologies can also be used for stormwater management in refugee camps. These include using rain water butts to collect rainwater from the roof of tents and using storage tanks to store collected water [44].
Water collected can be used for cooking, drinking, laundry and other purposes and can also be stored for use during dry seasons to prevent drought in the camps [45]. Figure 9(b) below illustrates stormwater management using container based technology.

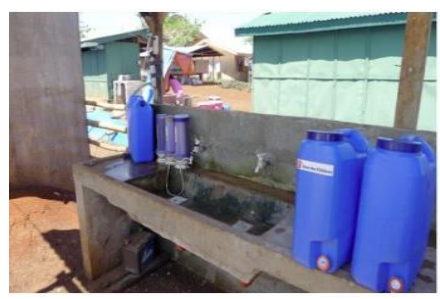
greywater collection in jerrycans from laundry to be reused for irrigation in the camps (Source: Spuhler, 2012 as cited by Zech et al., 2016).
Figure 9(a). Illustration of

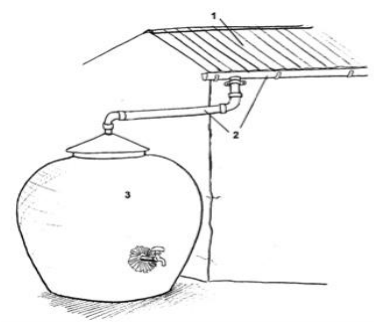

Figure 9(b). Illustration of rainwater collection from roof of a tent and storage in tank for use in the camps (Source: Gur and Spuhler, 2016).

\subsection{Proposed blackwater management technologies in refugee camps}

\subsubsection{Urine Diversion Dry Toilets (UDDT)}

As a result of high level of pollutants in blackwater, the most efficient and economic approach is source-separation technologies [43]. Such technologies ensure that faeces and urine are separately collected at the points of generation in the camps. Example of source separation technology is the Urine Diversion Dry Toilet (UDDT). The UDDT is a novel toilet technology that effectively separates faeces and urine at the point of generation [47]. In the UDDT system, faeces are directed to a water-tight dehydration vault to be dried and safely disposed or reused as fertilizer and urine is collected and stored in tanks or jerrycans to be used directly as liquid fertilizer [43]. Figure 10 below illustrates various options of the UDDT.
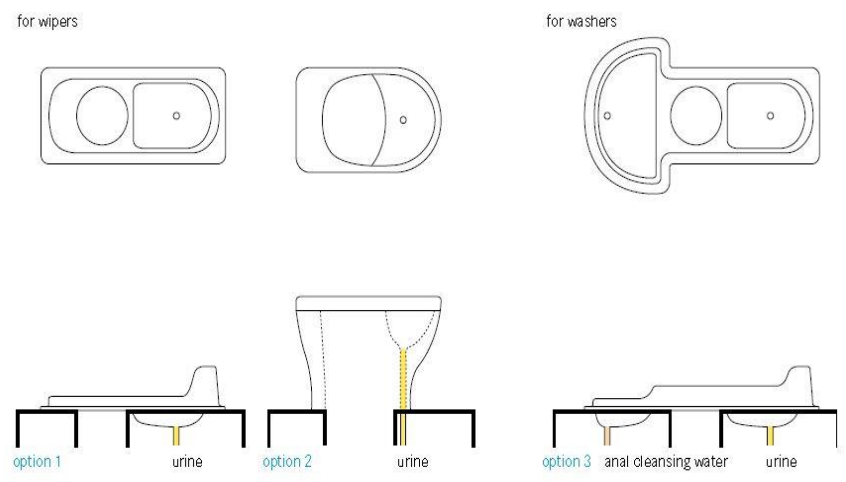

Figure 10. Various options of UDDT for blackwater management in the camps (Source: Tilley et al., 2014)

The main advantages of UDDT as potential blackwater management technology in CAR and South Sudan refugee and IDP camps include [43,47]:

- Low operation and maintenance cost,

- It prevents contamination of groundwater and the environment, as the blackwater generated is separated into reusable products,

- Simple to design and build using concrete or plastic 
- High possibility of using local competence of the refugees and IDPs for its construction, operation and maintenance, and

- High compatibility with existing systems.

\subsubsection{Constructed wetlands $(\mathrm{CW})$}

One of the most sustainable and low cost wastewater treatment technologies for treating highly polluted waste streams such as blackwater is constructed wetlands (CW) $[3 ; 48]$. The treatment capability of the $\mathrm{CW}$ is due to its ability to utilise the natural functions of wetland vegetation, soils and their microbial populations to treat contaminants in surface water, groundwater or waste streams [49]. Constructed Wetlands can achieve treatment efficiency of $90 \% \mathrm{BOD}_{5}$, $89 \%$ Total Suspended Solids (TSS), 56\% Total Phosphorus (TP), 43\% Total Nitrate (TN) and 73\% Ammonium Nitrate removal [49]. Figure 11 below illustrates the use of CW for wastewater management in refugee camps.

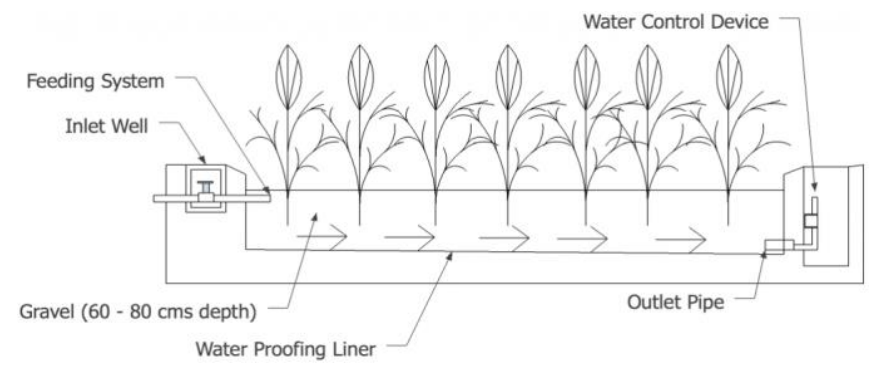

Figure 11. Illustration of Constructed Wetlands for wastewater management in refugee camps (Source: Masi and Bresciani, 2016).

\section{CONCLUSIONS}

To effectively overcome environmental challenges such as flooding and outbreak of water-related diseases in refugee and IDP camps across the world, effective surface water drainage and wastewater management infrastructure must be provided in the camps. Ideal technologies for surface water drainage and wastewater management in the camps must be operative in keeping the camps free of stagnant water, mitigate flooding, protect the environment, prevent contamination of drinking water sources and groundwater and encourage sustainable use of water in the camps. Factors that must be considered in selecting appropriate technologies for surface water drainage and wastewater management in the camps must include low-cost of construction, ease of maintenance, ease of implementation, sustainability and effectiveness. Selecting appropriate technologies for surface water drainage and wastewater management in the camps can effectively mitigate flooding, prevent contamination of drinking water by wastewater, prevent breeding of disease pathogens, reduce cost of providing water for the refugees and IDPs, make more water available for the use of refugees and IDPs and transform wastewater to resource. In addition, adequate provision of storage water tanks for storing rainwater and recycled wastewater can help to prevent drought during dry seasons and reusing wastewater for irrigation can prevent famine across the camps.

\section{REFERENCES}

[1] Corcoran E., Nellemann, C., Baker E., Bos R., Osborn, D., Savelli H. (2010). Sick Water? The Central Role of Wastewater Management in Sustainable Development, United Nations Environment Programme, UNHABITAT, GRID-Arendal., Norway.

[2] Marques P.A.S.S., Rosa M.F., Mendes F., Collares P.M., Blanco J., Malato, S. (1997). Wastewater detoxification of organic and inorganic toxic compounds with solar collectors, Periodical, vol. 108, no. 1, pp. 213-220.

[3] Mara D. (2003). Domestic wastewater treatment in developing countries, Earthscan, 8-12 Camden High Street, London, NW1 0JH, UK.

[4] Kabra K., Chaudhary R., Sawhney R.L. (2004). Treatment of Hazardous Organic and Inorganic Compounds through Aqeous-Phase Photocatalysis: A Review, vol. 43, no. 24, pp. 7683-7696.

[5] Alford-Daniel D., Allen C., Arne A.S., Angeloni M., Antheunissens E., Ashmore J., Baroni G., Bramucci G., Cameira J., Derkinderen S., Erb S., Etienne F., Federici G., Hodgkin M., Hoffman C., Kelly B., Motus N., Ringel S., Roberson K., Ryan K., Stone D., Vogel V., Vyas K., White P., Zarins J. (2015). Camp Management Toolkit, International Organization for Migration (IOM), Norwegian Refugee Council (NRC) and UN Refugee Agency (UNHCR).

[6] AMCA (2016). Mosquito-Borne Diseases, American Mosquito Control Association, United States of America.

[7] Tota-Maharaj K. (2016). WASH in Emergencies Problem Exploration Report - Surface Water Drainage, Humanitarian Innovation Fund, ELRHA.

[8] Spencer S., Grant A.D., Piola P., Tukpo K., Okia M., Salignon P., Genevier C., Kiguli J., Guthmann J.P. (2004). Malaria in camps for internally displaced persons in Uganda: evaluation of an insecticide-treated bednet distribution programme, Periodical, vol. 98, no. 12 , pp. 719-727.

[9] Hershe C.L., Doocy S., Anderson J., Haskew C., Spiegel P., Moss W.J. (2011). Incidence and Risk Factors for Malaria, Pneumonia and Diarrhea in Children under 5 in UNHCR Refugee Camps: A retrospective study, Periodical, vol. 5, no. 1, pp. 24.

[10] VOA Health Report (2012). Refugee Camps are Breeding Ground for Diseases, VOA.

[11] Kamugisha C., Cairns K.L., Akim. C. (2003). An outbreak of measles in Tanzanian Refugee Camps, Periodical, vol. 187, pp. S58-S62.

[12] CDC (2012). Measles - Horn of Africa, 2010-2011, Periodical, [Online], vol. 61, no. 34, pp. 30 Oct 2016678 - 684. Available from: https://www.cdc.gov/mmwr/preview/mmwrhtml/mm61 34a4.htm. [30 Oct 2016].

[13] CDC (2013). Investigation of Hepatitis E Outbreak Among Refugees - Upper Nile, South Sudan, 2012 2013, Periodical, [Online], vol. 62, no. 29, pp. 581586. Available

from: https://www.cdc.gov/mmwr/preview/mmwrhtml/mm62 29a2.htm. [30 Oct 2016].

[14] Brusin S. (2000). The Communicable Disease Surveillance System in the Kosovar Refugee Camps in the Former Yugoslav Republic of Macedonia April Aug 1999, Periodical, vol. 54, no. 1, pp. 52-57. 
[15] Carter R.C. (ed) (2015). Water Sanitation and Hygiene in Humanitarian Contexts: Reflections on current practice, Key writings on WASH in international development.

[16] Parkinson J., Lüthi C., Walther D. (GIZ). (2014). Sanitation21 - A Planning Framework for Improving City-wide Sanitation Services. IWA, Eawag-Sandec, GIZ.

[17] Ersel M. (2015). Water and sanitation Standards in Humanitarian Action, Turk J Emerg Med, vol. 15, no. 1, pp. 27-33.

[18] Bilak A. Caterina M., Charron G., Crozet S., DíazLeal L.R., Foster F., Ginnetti J., Giorgi J., Glatz A., Guyon K., Howard C., Kesmaecker-Wissing, M., Kilany, S., Klos, J., Kok, F., McCallin, B., Pagot, A., Rushing, E., Spurrell, C., Swain, M., Turner, W., Walicki, N., Yonetani, M. (2015). Global Overview 2015 - People internally displaced by conflict and violence, Internal Displacement Monitoring Centre, Norwegian Refugee Council Chemin de Balexert 7-9 CH-1219 Châtelaine (Geneva).

[19] ECHACP (2016). ECHO FACTSHEET - Central African Republic, European Commission Humanitarian Aid and Civil Protection.

[20] UNHCR (2016a). CAR Emergency - Case Study of the Central African Republic Crisis Hardship and Resilience, United Nations High Commissioner for Refugees.

[21] Google Maps (2016a). Location of Central African Republic on the Continent of Africa.

[22] Google Maps (2016b). Location of Central African Republic and its neighbouring countries on the continent of Africa.

[23] Varma A. (2011). The Creation of South Sudan: Prospects and Challenges, Observer Research Foundation, New Delhi.

[24] Berry L. (2015). Sudan a country study, 5th edn, Federal Research Division Library of Congress, U.S.A.

[25] UNHCR (2016b). 60,000 flee South Sudan's recent violence to nearby countries, United Nations High Commissioner for Refugees.

[26] Google Maps (2016c). Location of South Sudan on the continent of Africa

[27] Google Maps (2016d). Illustration of migration of refugees from neighbouring countries into South Sudan.

[28] Laccino L. (2014). World Refugee Day 2014: Living Conditions in the Largest Refugee Camps, International Business Times.

[29] Oxfam (2014). Technical Brief Hepatitis E Outbreak Response, Oxfam, Humanitarian Innovation Fund.

[30] McDonald A. (2012). South Sudan's refugee camps flooded - in pictures, The Guardian. [Online]. Available from: https://www.theguardian.com/globaldevelopment/gallery/2012/sep/27/south-sudan-refugeecamps-flooded.

[31] Winblad U. (1997). Towards an Ecological Approach to Sanitation, Swedish International Development Cooperation Agency, Department for Natural Resources and the Environment S-105 25 Stockholm, Sweden.

[32] Woods-Ballard B., Kellagher R., Martin P., Jefferies, C., Bray, R., Shaffer, P. (2011). The SuDS Manual, CIRIA, Classic House, 174-180 Old Street, London EC1V 9BP.
[33] Greater Dublin Strategic Drainage Study (2016). Filter Drains, Environmental Management Policy.

[34] Ministry of Roads and Bridges Government of South Sudan (2013). South Sudan Low Volume Roads Design Manual, Government of South Sudan.

[35] Cambridge SuDS Design and Adoption Guide (2016). Swales and Filter Strips, Technical Report edn, Cambridge SuDS Design and Adoption Guide, UK.

[36] Udale-Clarke, H. (2016). The Multiple Benefits of the new CIRIA SuDS Manual 2015, Institution of Civil Engineers (ICE), UK, [Online]. Available: https://www.ice.org.uk/disciplines-and-resources/casestudies/the-benefits-of-the-new-cira-suds-manual-2015 [2016, November/05].

[37] Auckland Council (2016). Tree Pits Construction Guide, Stormwater device information series edn, Auckland Council.

[38] IRG (2007). South Sudan Environmental Threats and Opportunities Assessment - Biodiversity and Tropical Forest Assessment, International Resources Group, 1211 Connecticut Avenue, NW, Suite 700 Washington, DC 20036.

[39] Scholz M. (2015). Sustainable Drainage Systems, Water vol. 7, no. 5, pp. 2272-2274. DOI: $10.3390 / \mathrm{w} 7052272$

[40] Chu W., Ng F. (2000). Upgrading the conventional grease trap using a tube settler, Environment International, vol. 26, pp. 17-22.

[41] FEBCO Company (2007). Grease traps (new products) Reeves Journal, Vol.87 (3), p.86 (1).

[42] City of Carrollton Grease Interceptor Sizing Requirements (2012). Guidance Document for Sizing and Installation of Grease Traps and Interceptors, Carrollton, Texas, USA.

[43] Tilley E., Ulrich L., Luethi C., Reymond P., Zurbruegg C. (2014). Compendium of Sanitation Systems and Technologies, IWA Publishing.

[44] Fewkes A., Butler D. (2000). Simulating the performance of rainwater collection and reuse systems using behavioural models, Building Services Research and Technology, vol. 21, pp. 99-106, CIBSE.

[45] Gur E. and Spuhler D. (2016). Rainwater Harvesting (Rural), Sustainable Sanitation and Water Management. [Online] Available from: http://www.sswm.info/category/implementationtools/water-sources/hardware/precipitationharvesting/rainwater-harvesting-r. [28 Dec. 2016].

[46] Zech E., Spuhler D., Miso A., Factura H. (2016). SSWM Case Study XU Ecoville - an example of planning and implementing SSWM approaches in the Philippines. [Online]. Available from: http://www.sswm.info/content/sswm-case-study-xuecoville--example-planning-and-implementing-sswmapproaches-philippines. [28 Dec. 2016].

[47] Flores A., Buckley C., Fenner R. (2008). Selecting Wastewater Systems for Sustainability in Developing Countries, 11th International Conference on Urban Drainage, Edinburgh, Scotland, UK, 2008.

[48] Kadlec R.H., Wallace S.D. (2009). Treatment Wetlands, 2nd edn, CRC Press.

[49] Vymazal J. (2010). Constructed Wetlands for Wastewater Treatment, Full, no. 2, pp. 530-549.

[50] Masi F., Bresciani R. (2016). Horizontal Flow Constructed Wetlands, Sustainable Sanitation and Water Management. [Online]. Available from: http://www.sswm.info/category/step-nawatech/m1- 
nawatech-basics/appropriate-technologies/appropriate-

technologies/conte-13. [28 Dec. 2016]. 